\title{
Internal Control, Asset Substitution and Creditor Protection
}

\author{
Weiping Huang, Panpan Long \\ Management School, Jinan University, Guangzhou, China \\ Email: Ipp901001@163.com
}

Received 18 March 2015; accepted 16 April 2015; published 23 April 2015

Copyright (C) 2015 by authors and Scientific Research Publishing Inc.

This work is licensed under the Creative Commons Attribution International License (CC BY). http://creativecommons.org/licenses/by/4.0/

(c) (i) Open Access

\begin{abstract}
At present, the main ways of protecting the interests of creditors include adjusting the new debt scale, reducing the interest rate and adjusting the debt capital cost. In this paper, from a new perspective of the principal-agent, this article tries to explore whether the internal control can protect the interests of the creditors. Through the study, we found that the higher the quality of internal control of listed companies, the less the occupied money by assets substitution of controlling shareholders.
\end{abstract}

Keywords

Internal Control, Asset Substitution, Capital Occupied, Creditor Protection

\section{Introduction}

For a long time, the protection of rights and interests plays an important role in multiple disciplines, such as economics, law, accounting and other research priorities. And the protection of rights and interests focuses on investor protection. In fact, the equity structure is more unique in China, law for protecting investors is not perfect, the corporate bond market is under-developed and the state-owned commercial banks are the largest creditors of listed companies in China [1]. In the capital markets, the information is asymmetric and the economic man is limited rationality, so that the interests of creditors have been ignored. Creditors can only obtain fixed interest which has been claused in the contract, even the company earned fat profits. But once the company is deficit or bankruptcy, the creditors undertake the major losses. Based on the complex environment in China, it is a very meaningful research topic to study how to prevent creditors' legitimate rights and prevent the creditors' interests from occupying by shareholders and managers.

\section{Literature Review}

Jensen and Meckling (1976) proposed the "asset substitution effect”, namely, In the case of high debt levels, 
shareholders and managers have strong incentives to invest in projects with high risk [2]. Since shareholders and managers will get most benefit once the investment get succeed. However, in case of failure, creditors will bear the main consequences because of the limited liability of shareholders and managers. Moreover, Myers (1997) evident that shareholders and managers might ignore some projects which have positive NPV (net present value) under some certain conditions [3]. As the benefit from these projects are mainly belongs to creditors which decrease the incentives of them to invest in these projects, namely under-investment.

Smith and Warner (1979) designed questionnaire according to restrictive clauses in debt contracts and get further conclusion that internal staff can infringe the legitimate rights of creditors by the following four ways: dividend policy, debt dilution, asset substitution and under-investment [4].

Doyle (2009) concentrated on information symmetry and suggested that internal control can protect the interests of creditors by improving the accounting quality of enterprises, reducing the information asymmetry between internal and external and helping external investors make better decisions [5].

$\mathrm{Li}$ and Yang (2013) found that creditors will perceive signal of protection and then willing to ease the debt contract conditions when the level of quality of internal control is relatively high [6]. At this time, creditors tend to hold more debenture capital and have the preference for lower cost of debenture capital and longer debt maturity.

In the principal-agent relationship of managers/shareholders and creditors, Jiang and Shen (2005) think that the controlling shareholders violate the interests of the creditors by the way of asset-substitution from the debt agency-cost perspective [7]. During to the deviation of interest, Li (2012) argues that the controlling shareholders can influence the corporate governance by making financial decisions in various ways [8]. However, the creditors often get to know whether the assets are unreasonable occupation or not only by the means of the disclosure of information. Thus, the level of the quality of internal control will significantly affect the asset-substitution that caused by controlling shareholders, the high quality of internal control system is in favor of protecting the interests of creditors. Based on the above analysis, we propose the hypothesis:

The higher the quality of internal control of listed companies, the less money the controlling shareholders occupied by the way of asset substitution behavior.

\section{The Index System}

Based on the above analysis and assumption, the detail of the dependent variable, independent variable and control variables in this article are as follows.

\subsection{Dependent Variable}

“Tunneling” (TUN). Controlling shareholder "tunneling” the funds of listed companies usually by the way that occupied receivables from the related party transactions or other receivables from "temporary loan" [9]. Compared to the accounts receivable which mainly consist of sales transactions, other receivables seems more covert, thus become the main content of "tunneling" funds which occupied by the controlling shareholders. Other receivables to total assets ratio was measured as the funds tunneling by shareholder/manager (TUN).

\subsection{Independent Variable}

Quality of internal control (LNICQ). There are three ways to measure this indicator. Firstly, based on the disclosed information of internal control to determine indicators. Secondly, by setting a questionnaire to evaluate the quality of internal control. Lastly, to construct an internal control index which evaluate the quality of internal control by using the weighted method. This article used the third method. The quality of internal control in this paper was constructed by the jointly research group of internal control index by Sun Yat-sen University and Shenzhen DIB Enterprise Risk Management Co., Ltd. The database has been widely recognized.

\subsection{Control Variables}

Guarantee capacity (ASSU). ASSU is measured by the ratio of the net fixed assets, the net inventory to the total assets at the end of the year. As we all know, the debtor's ability to guarantee the important reasons is the impact of debt size, duration, cost, etc. 
The company's growth (GROWTH). Chen (2009) showed that the high-growth companies presence underinvestment behavior, low growth companies exist asset substitution behavior. Listed companies under different growth through different ways to "tunneling" the interests of creditors [10].

Financial risk level (LEV). Under the condition of high financial risk, the creditor is difficult to obtain stable interest, even the principal will not be repaid. In this paper, measured by asset-liability ratio.

The net cash flow of each asset (CASHPS). Cash flow is an important guarantee to ensure that creditors can rapid recovery the principal, in this paper, CASHPS measured by the end of net cash flow to total assets ratio.

The nature of the first major shareholder (SHAERC). Yang Deming, Feng Xiao (2007, 2008) their empirical research shows that, the internal control of high quality enterprise can get more money, but this phenomenon exists only in state-owned-enterprises [11]. Therefore, the nature of the largest shareholder of control variables, as a dummy variable, 1 for the state-owned enterprises, 0 for the non-state-owned enterprises.

\subsection{Data}

The data used in this paper included all of the A-share companies which were listed in the main board in China from 2011 to 2013. These years that release the internal control self-assessment report. The dependent variable and the data come from the database GTA CSMAR, the disclosure quality data of internal control information comes from DIB internal control and risk management database, and the data statistics and analysis is proceed by Excel, STATA, SPSS. And in accordance with the following methods of screening samples, removing the financial and insurance public companies; removing the sample companies which their variable data is incomplete or missing values; then continuous variables around $2 \%$ were handled by Winsorize to eliminate the influence of extreme values. A total of 3537 observations were obtained after filtering and sorting.

\section{Empirical Analysis}

\subsection{Descriptive Statistical Analysis}

Table 1 presents the details of descriptive statistics, such as minimum, maximum, mean and variable.

Table 2 presents the details of grouping descriptive statistics. According to the median value of the quality of internal control index, 6.534, the observations was divided into two parts, the high-quality observations of internal control group and the low-quality of internal control group, and so we did another independent samples T-test, the test results are shown in Table 2. Under the high level of internal control, taking the mean of the funds TUN (mean $=0.018$ ), lower than the 0.020 level low quality of internal control. From the comparison of the data which can come to the preliminary conclusion, that the higher the quality of internal control of listed companies, the less money the controlling shareholder occupied by asset substitution behavior. This result demonstrates the initial hypothesis.

\subsection{Correlation Analysis}

Correlation coefficient of the relationship between each variable matrix as shown in the Table 3, from a general point of view, firstly, the correlation coefficient of TUN and LNICQ is - 0.065, at the level of 0.01 was significantly of negatively correlate so that the results further validate the hypothesis; secondly, variable settings is more in line with expectations, the independent variables and control variables have significant influence on the dependent variable. In the regression process we carry out VIF test, there is no serious multi-collinearity.

Table 1. Presents the details of descriptive statistics.

\begin{tabular}{cccccc}
\hline Variables & Obs. & Min & Max & Mean & 0.019 \\
\hline TUN & 3537 & 0.000 & 0.118 & 6.521 & 0.025 \\
LNICQ & 3537 & 6.239 & 6.808 & 0.447 & 0.187 \\
ASSU & 3537 & 0.069 & -0.976 & 7.927 & 0.270 \\
GROWTH & 3537 & 0.157 & 0.935 & 0.554 & 0.130 \\
LEV & 3537 & 0.011 & 0.423 & 0.188 \\
CASHPS & 3537 & 0.000 & 1.000 & 0.060 \\
SHAREC & 3537 & & 0.243 \\
\hline
\end{tabular}


Table 2. Grouping descriptive statistics.

\begin{tabular}{|c|c|c|c|c|c|c|c|c|}
\hline Variables & Quality & $\mathrm{N}$ & Mean & Std. dev & F & Sig. & $\mathrm{t}$ & Sig. \\
\hline \multirow{2}{*}{ TUN } & 1 & 1761 & 0.018 & 0.023 & \multirow{2}{*}{32.584} & \multirow{2}{*}{$0.000^{* * *}$} & \multirow{2}{*}{-3.419} & \multirow{2}{*}{$0.001^{* * * *}$} \\
\hline & 0 & 1776 & 0.020 & 0.027 & & & & \\
\hline \multirow{2}{*}{ LNICQ } & 1 & 1761 & 6.605 & 0.071 & \multirow{2}{*}{146.443} & \multirow{2}{*}{$0.000^{* * *}$} & \multirow[b]{2}{*}{63.351} & \multirow{2}{*}{$0.000^{* * * *}$} \\
\hline & 0 & 1776 & 6.437 & 0.086 & & & & \\
\hline \multirow{2}{*}{ ASSU } & 1 & 1761 & 0.446 & 0.184 & \multirow{2}{*}{0.685} & \multirow{2}{*}{0.408} & \multirow{2}{*}{-0.408} & \multirow{2}{*}{0.683} \\
\hline & 0 & 1776 & 0.449 & 0.189 & & & & \\
\hline \multirow{2}{*}{ GROWTH } & 1 & 1761 & 0.316 & 1.339 & \multirow{2}{*}{0.202} & \multirow{2}{*}{0.653} & \multirow{2}{*}{2.030} & \multirow{2}{*}{$0.042^{* *}$} \\
\hline & 0 & 1776 & 0.226 & 1.296 & & & & \\
\hline \multirow[b]{2}{*}{ LEV } & 1 & 1761 & 0.562 & 0.181 & \multirow[b]{2}{*}{11.868} & \multirow{2}{*}{$0.001^{* * *}$} & \multirow[b]{2}{*}{2.427} & \multirow{2}{*}{$0.015^{* *}$} \\
\hline & 0 & 1776 & 0.547 & 0.196 & & & & \\
\hline \multirow{2}{*}{ CASHPS } & 1 & 1761 & 0.136 & 0.093 & \multirow{2}{*}{0.921} & \multirow{2}{*}{0.337} & \multirow{2}{*}{3.734} & \multirow{2}{*}{$0.000^{* * *}$} \\
\hline & 0 & 1776 & 0.125 & 0.091 & & & & \\
\hline \multirow[b]{2}{*}{ SHAREC } & 1 & 1761 & 0.052 & 0.221 & \multirow[b]{2}{*}{29.607} & \multirow[b]{2}{*}{$0.000^{* * *}$} & \multirow[b]{2}{*}{-2.710} & \multirow[b]{2}{*}{$0.007^{* *}$} \\
\hline & 0 & 1776 & 0.074 & 0.261 & & & & \\
\hline
\end{tabular}

Note. $\mathrm{N}=3537 ;{ }^{*} p<0.05 ;{ }^{* *} p<0.01 ;{ }^{* * *} p<0.001$.

Table 3. Correlation analysis.

\begin{tabular}{|c|c|c|c|c|c|c|c|}
\hline Variables & TUN & LNICQ & ASSU & GROWTH & LEV & CASHPS & SHAREC \\
\hline TUN & 1.000 & & & & & & \\
\hline LNICQ & $-0.065^{* *}$ & 1.000 & & & & & \\
\hline ASSU & $-0.155^{* *}$ & -0.014 & 1.000 & & & & \\
\hline GROWTH & $0.071^{* *}$ & $0.037^{*}$ & -0.015 & 1.000 & & & \\
\hline LEV & $0.145^{* *}$ & -0.009 & $0.267^{* *}$ & $0.072^{* *}$ & 1.000 & & \\
\hline CASHPS & -0.010 & $0.096^{* *}$ & $-0.405^{* *}$ & -0.006 & $-0.318^{* *}$ & 1.000 & \\
\hline SHAREC & $0.053^{* *}$ & $-0.058^{* *}$ & 0.014 & $0.033^{*}$ & $0.052^{* *}$ & -0.016 & 1.000 \\
\hline
\end{tabular}

Note. $\mathrm{N}=3537 ;{ }^{*} p<0.05 ;{ }^{* *} p<0.01 ;{ }^{* * *} p<0.001$.

\subsection{Regression Analysis}

Table 4 presents the regression analysis results. As shown in Table 4, the coefficient of LNICQ is negative, revealed that TUN was negatively correlated with LNICQ $(\beta=-0.014, p<0.001)$. Further analysis, we can clearly know that control variable and LNICQ have a significant impact on TUN (adjusted $\mathrm{R}^{2}=0.07, p<0.001$ ) from the fourth column. In summary, Hypothesis is supported. The higher the quality of internal control of listed companies, the less money the controlling shareholder occupied by the way of asset substitution behavior.

\section{Conclusions}

The empirical results show that controlling shareholders often "tunneling" the benefit of creditors by the way of asset substitution behavior, specific performance of possession of the assets. But the high quality of internal control can alleviate this encroachment. It turned out to be that the internal control has the capability to protect the creditors. 
Table 4. Regression analysis.

\begin{tabular}{cccc}
\hline & \multicolumn{2}{c}{ TUN: Results of multiple regression analysis } & Sig. \\
\hline Variables & Coef. & $\mathrm{T}$ & $0.000^{* * *}$ \\
TUN & -0.014 & -3.866 & $0.000^{* * *}$ \\
LNICQ & -0.029 & -12.161 & $0.001^{* * *}$ \\
ASSU & 0.001 & 3.407 & $0.000^{* * *}$ \\
GROWTH & 0.025 & 10.695 & $0.079^{*}$ \\
LEV & -0.009 & -1.755 & $0.013^{* *}$ \\
CASHPS & 0.004 & 2.497 & $0.000^{* * *}$ \\
SHAREC & 0.108 & 4.695 & 45.268 \\
Adjusted R
\end{tabular}

Note: $\mathrm{N}=3537 ;{ }^{*} p<0.05 ;{ }^{* *} p<0.01 ;{ }^{* * *} p<0.001$.

The protection of creditors also affected by other factors, such as the net cash flow per share (CASHPS), the ability to grow (GROWTH) and other business management indicators. The profitability and growth of listed companies are guarantees for the creditors. Moreover, audit opinion, as another independent factor, it seems to be more trustworthiness, and it can improve the reliability of financial information. At last, the listed companies which issued standard audit opinions would protect the interests of creditors.

The above study and its conclusions, breaking the previous study that the internal control of investor protection focused mostly on the equity investors, selected an innovative angle of creditors, which enriched the research in this field.

\section{Suggestion}

Above results revealed that, in currently, we should not only strengthen the protection of minority shareholders of listed corporations, but also pay more attention to protect creditors of those companies. At present, China's listed companies to establish a sound internal control system of work is in full swing, which is both bigger and stronger foundation to promote the company, but also for the stable development of the capital markets provide an important safeguard. This study shows that improving the quality of internal control can effectively protect the interests of creditors. In order to better promote the role of the internal control and reflect the value, the paper makes two suggestions.

Recommended the introduction of laws and regulations clearly to constraint listed companies of disclosing internal control behavior. Government departments and regulatory bodies have introduced appropriate laws and regulations, to require listed companies to establish a sound internal control system, and guide the implementation of the internal control system of listed companies. But the lack of clearly defined if the internal control of listed companies exist a defect or other problem, there are no appropriate laws and regulations shall be punished. In response to this phenomenon, we recommend our reference 906 US SOX Act, the introduction of appropriate laws and regulations on concealed internal control deficiencies, the effectiveness of internal control false disclosure of listed companies be severely punished, so as to promote the healthy development of China's capital market.

Established industry benchmark of internal control. Regulatory agencies can promote the norms of internal control combined with the implementation plan. Then selecting the enterprises of high quality of internal control as the industry benchmark, so that other listed companies can establish their internal control system within the guidance of this industry. The organization of industry experts regularly evaluate and improve internal control standards, so that to provide some reference for the construction of the listed company's internal control system.

\section{References}

[1] Xiao, Z.P. and, Liao, L. (2007) Major Shareholder, Creditor Protection and Corporate Debt Maturity Structure Choice. Management World, 10, 99-113. 
[2] Jensen, M. and Meckling, W. (1976) Theory of the Firm: Managerial Behavior, Agency Costs, and Ownership Structure. Journal of Financial Economics, 3, 305-360. http://dx.doi.org/10.1016/0304-405X(76)90026-X

[3] Myers, S. (1977) Determinants of Corporate Borrowing. Journal of Financial Economics, 5, 147-175. http://dx.doi.org/10.1016/0304-405X(77)90015-0

[4] Smith, W. (1979) On Financial Contracting: An Analysis of Bond Covenants. Journal of Financial Economics, 7, 117161. http://dx.doi.org/10.1016/0304-405X(79)90011-4

[5] Jeffrey, D. and Weili, G. and Sarah, M. (2006) Determinants of Weaknesses in Internal Control over Financial Reporting and the Implications for Earning Quality. Accounting Horizons, 5, 67-75.

[6] Li, X.H. and Yang, Z.X. (2013) The Quality of Internal Control and Creditor Protection, Based on the Perspective of Debt Contract Characteristics. Audit and Economic Research, 2, 97-105.

[7] Jiang, W. and Shen, Y.F. (2005) Big Shareholder Control, Asset Replacement, and Creditor Protection. Study of Finance and Economics, 12, 95-106.

[8] Li, J.L. (2012) Information Disclosure of Investor Protection Effect Research. Jinan University, Guangzhou, 23-26.

[9] Heather, M.H. (2000) An Analysis of the Demand for Reporting on Internal Control. Accounting Horizons, 3, 325-341.

[10] Chen, J. and Xu, Y.D. (2012) Executive Compensation Incentive Will Focus on the Creditors' Interests-City of the Company’s Debt Maturity Constraint Perspective Empirical Evidence. Accounting Research, 9, 73-82.

[11] Yang, D.M. and Feng, X. (2011) Bank Loans and Debt Maturity and Internal Control of Listed Companies. Journal of Shanxi University of Finance and Economics, 8, 44-50. 